\title{
First record of the Borneo Earless Monitor Lanthanotus borneensis (Steindachner, 1877) (Reptilia: Lanthanotidae) in West Kalimantan (Indonesian Borneo)
}

\author{
B. Yaap ${ }^{1}$, G.D. Paoli ${ }^{2}$, A. Angki ${ }^{3}$, P.L. Wells ${ }^{4} \&$ D. Wahyudi ${ }^{5}$ \& M. Auliya ${ }^{6}$ \\ 1,2,3,4 Daemeter Consulting, Jl. Tangkuban Perahu No 6, Bogor, West Java 16151, Indonesia \\ ${ }^{1}$ Centre for Tropical Environmental and Sustainability Science (TESS) \& School of Marine and Tropical Biology, James Cook \\ University, Cairns, Queensland 4878, Australia \\ ${ }^{5}$ PT Rea Kaltim Plantations, Conservation Department, Jl. Hasan Basri No.21A, Samarinda, East Kalimantan 75117, Indonesia \\ ${ }^{6}$ Helmholtz Centre for Environmental Research - UFZ, Permoserstr. 15, 04318 Leipzig, Germany \\ Email: ${ }^{1}$ betsy.yaap@my.jcu.edu.au, ${ }^{2}$ gary.paoli@daemeter.org, ${ }^{3}$ agnes.angki@daemeter.org, ${ }^{4}$ philip.wells@daemeter.org, \\ ${ }^{5}$ jiwalakaji@yahoo.com, ${ }^{6}$ mark.auliya@ufz.de (corresponding author)
}

Abstract: The following paper presents the first published record of the cryptic Borneo Earless Monitor (Lanthanotus borneensis Steindachner, 1877) from West Kalimantan (Indonesian Borneo). This sole member of the family Lanthanotidae is endemic to Borneo. Since its description in 1877, all locality records of specimens refer to Sarawak (Malaysian Borneo). The recent discovery of this "living fossil" in an oil palm estate under development in Landak District expands its known distribution southward to Kalimantan. This paper (i) describes the circumstances of the discovery, characteristics of the individual and microhabitat structure in which it was found, (ii) provides results from local community interviews about the local distribution of the species, suggesting it is found more broadly in the Landak District and possibly elsewhere, and (iii) places this information in a broader context of current knowledge and high conservation value of $L$. borneensis.

Keywords: Biodiversity, biogeography, conservation, Indonesia, Kalimantan, Lanthanotus borneensis, oil palm.

Date of publication (online): 26 September 2012

Date of publication (print): 26 September 2012

ISSN 0974-7907 (online) | 0974-7893 (print)

Editor: Wolfgang Böhme

Manuscript details:

Ms \# 03055

Received 05 January 2012

Final received 01 June 2012

Finally accepted 11 September 2012

Citation: Yaap, B., G.D. Paoli, A. Angki, P.L. Wells \& D. Wahyudi \& M. Auliya (2012). First record of the Borneo Earless Monitor Lanthanotus borneensis (Steindachner, 1877) (Reptilia: Lanthanotidae) in West Kalimantan (Indonesian Borneo). Journal of Threatened Taxa 4(11): 3067-3074.

Copyright: @ B. Yaap, G.D. Paoli, A. Angki, P.L. Wells \& D. Wahyudi \& M Auliya 2012. Creative Commons Attribution 3.0 Unported License. JoTT allows unrestricted use of this article in any medium for non-profit purposes, reproduction and distribution by providing adequate credit to the authors and the source of publication.

Acknowledgements: The authors wish to acknowledge Jeremy Goon, Simon Siburat, Sinnaya Satappan, Walter Mahibol and Edrin Moss from Wilmar International for enabling the survey, community members of Kecamatan Jelimpo, and Alfa Ratu Simarangkir for their participation in the survey. We thank James Smith and Djoko Iskandar for initial species identification. We also thank Oswald Braken, Ulla Bott and Rene Bonke for assistance with acquiring literature.

\section{OPEN ACGESS | FREE DOWNLOAD}

Bahasa Indonesia Abstract: Abstrak: Makalah (paper) berikut menjelaskan publikasi pertama kali dari Borneo Earless Monitor (Lanthanotus borneensis Steindachner, 1877) yang tersamar dari Kalimantan Barat (Borneo Indonesia). Satu-satunya anggota dari famili Lanthanotidae ini bersifat endemis di Borneo. Sejak penggambarannya pada tahun 1877 , semua catatan lokalitas dari spesimen tersebut merujuk ke Sarawak (Borneo Malaysia). Penemuan "fosil hidup" belakangan ini di sebuah kebun sawit yang sedang dibangun di Kabupaten Landak memperluas distribusinya yang diketahui ke arah selatan Kalimantan. Makalah (paper) ini (i) menjelaskan keadaan penemuan, karakteristik dari struktur individu dan habitat mikro tempat ditemukannya, (ii) memberikan hasil dari wawancara masyarakat lokal mengenai sebaran lokal dari spesies ini, yang menunjukkan bahwa spesies tersebut ditemukan secara luas di Kabupaten Landak dan mungkin di mana-mana, dan (iii) menempatkan informasi ini dalam konteks pengetahuan terkini yang lebih luas dan nilai konservasi tinggi dari $L$. borneensis.

Explorations of Borneo's biodiversity date back to c.1820. This is much later than explorations of the other two Greater Sunda Islands, Sumatra and Java, as Borneo was "far off the commercial trade route of Europe" (Das 2004). Earliest herpetological collections from Borneo date from the turn of the $19^{\text {th }}$ century (Belcher 1848), while Hugh Low, a Scottish botanist, compiled the first herpetofaunal checklist of Borneo in 1848 (Low 1848). In 1890, Mocquard presented a herpetofaunal checklist for Borneo listing 29 amphibians and 155 reptiles.

Since then, our knowledge of Bornean herpetofauna has grown substantially, with 146 amphibians and 254 reptiles currently known to be native to Borneo (excluding sea snakes and sea turtles) (Malkmus et al. 2002; Auliya in prep.), while 151 amphibians and 244 reptile species (also excluding marine species) are known from Sarawak and Sabah (Das \& Yaakob 2007). Currently, no figures are available on the number of 
amphibians and reptile species native to Indonesian Borneo, yet there is clearly a sampling bias. For example, Mt. Kinabalu has been extensively sampled, and not surprisingly has representation of $47 \%$ of the known amphibians and reptile fauna for Borneo based on Malkmus et al. (2002). Although Mt. Kinabalu is an area of high endemicity, it is likely that many more species have gone undocumented in other areas of the island.

Borneo is a hub of endemicity for herpetofauna, with many species geographically restricted to the highlands in the island's north (MacKinnon et al. 1996; Malkmus et al. 2002). Highland species are generally protected from human-derived threats due to the more difficult terrain of these montane, forested habitats. In Borneo's lowlands, however, forest fires, swidden agriculture and widespread conversion to agro-industrial and forestry plantations have led to rapid forest loss and degradation (Curran et al. 2004). This loss is widely documented and viewed as a significant long-term threat to the island's species richness (e.g., Bodmer et al. 1991; Fuller et al. 2003; WWF Germany 2005). For herpetofauna, this has raised concern about the potential widespread loss of species prior to 'discovery' or collection of status data (e.g., Crocodylus siamensis), especially in Kalimantan where deforestation rates are high and many regions have gone unsurveyed.

The Borneo Earless Monitor Lanthanotus borneensis, a Bornean endemic previously known only from the coastal lowlands of northern Sarawak, exemplifies this concern (Image 1). This species was recently discovered during a biodiversity survey of an oil palm development area in the Landak District of West Kalimantan, expanding its known range southward into Kalimantan and a new bio-geographical sub-unit of the island (MacKinnon 1997).

This paper reports this exceptional herpetofaunal discovery resulting from surveys commissioned by a member of the voluntary Roundtable on Sustainable Palm Oil (RSPO) initiative (http://www.rspo.org). The surveys were commissioned by the company to

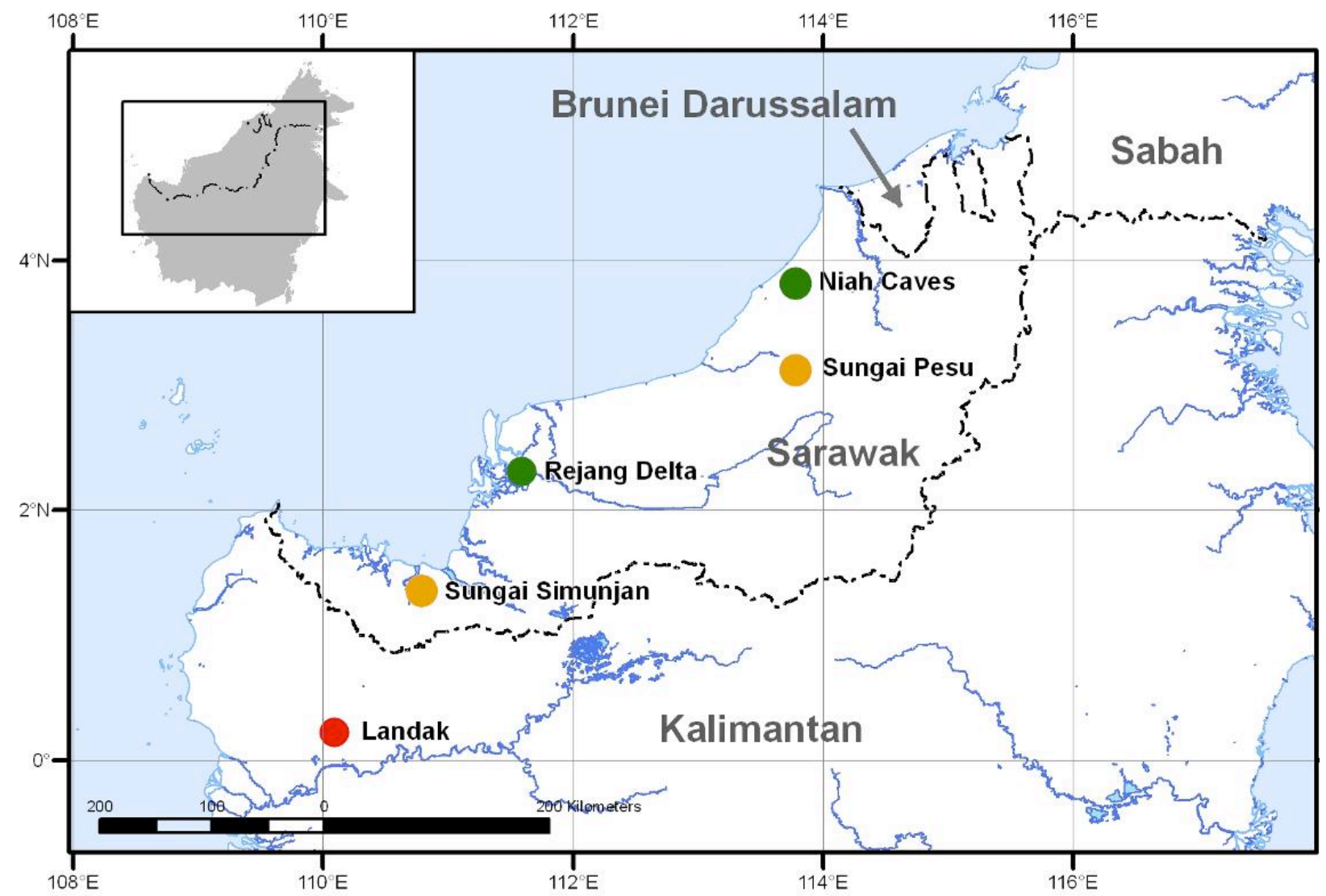

Image 1. Locations where Lanthanotus borneensis has been recorded. Green spots indicate findings from 1912-discoveries, yellow spots 1912-1966 and red spot 1966-present. 
help guide plantation development in a manner that minimizes biodiversity, environmental and social impacts, an emerging trend in the palm oil industry (Yaap et al. in press).

\section{The discovery, specimen, habitat}

On 30 May 2008, at 11:28hrs, a single specimen of $L$. borneensis was discovered under leaf litter in a shallow, rocky creek $(0.5-2 \mathrm{~m}$ wide) by a social survey team member taking GPS coordinates of locally important cultural sites. The survey team was ascending the shallow creek bed up a steep hill, and came to rest for lunch at a level area along the stream at approximately $260 \mathrm{~m}$ elevation. The lizard was spotted by a local community member, at this location (Image 2), partially submerged in the creek.

Upon sighting, the lizard was photographed in situ (Image 3) by survey team members, then picked up and examined by one of the local community guides who subsequently handed it to a member of the assessment team. After further photographing (Images 4 and 5), it was returned to the creek where it was originally found. The survey team resumed eating, during which time the lizard remained in the same position until the team continued walking upstream (one hour later). No effort was made to collect the animal, in part because the scientific import of the discovery was not fully appreciated. As the team resumed their walk, one member looked back to view the lizard again, but it had disappeared.

While being handled and photographed, the lizard was alive, as indicated by visible pounding of its throat, but remained almost completely motionless

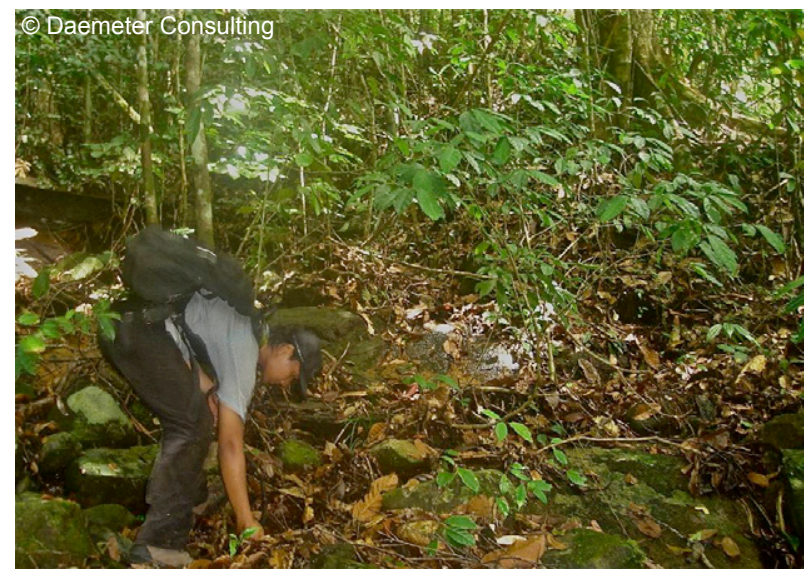

Image 2. Image of rocky, forest habitat near the shallow stream bed where the specimen was found. throughout the entire one-hour period. The lizard was not aggressive and moved minimally. The assessment team members describe the lizard as brownish-yellow, approximately $30 \mathrm{~cm}$ in total length (snout-tip to tail-tip), with small lumps that formed stripes along its dorsal side (Image 4). The ventral side was light colored with dark brown dots forming a striped pattern (Image 5).

The lizard was discovered in what is locally known as a tembawang forest - a mature fruit tree garden planted by local communities. Tembawang is usually planted with a predictable assemblage of useful trees (Durio, Mangifera, Nephelium, Garcinia, Lansium and Shorea spp.), but can also support many elements of the native flora. This particular tembawang is located in the Jelimpo sub-district of Landak District, West Kalimantan (marked in red in Image 1). Geographical coordinates were taken, however, due to the species' rareness and its high conservation value; it cannot be ruled out that pet reptile collectors and traders may misuse this additional information. We have therefore retained GIS data.

The tembawang forms part of a larger forest block which includes natural forest exhibiting various disturbance levels, secondary forest and isolated bamboo clusters - all located in a recently developed oil palm estate. The estate, and its surroundings, are a complex mosaic of active or recently abandoned swidden agricultural fields (ladang), rubber agroforestry, tembawang and secondary forest

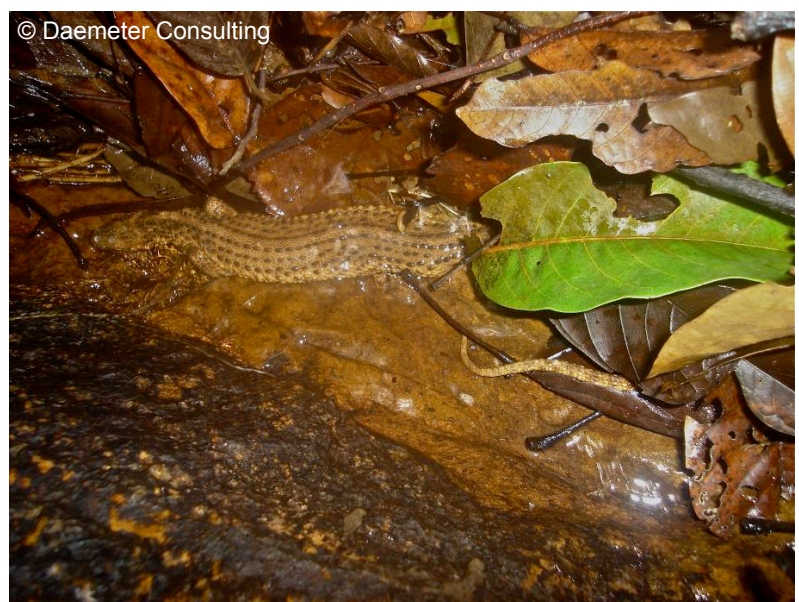

Image 3. Lanthanotus borneensis as it was found after sweeping back leaves that covered most of its body, but prior to being handled. $L$. borneensis is semi aquatic and known to retreat to water when under threat (Pianka \& Vitt 2003). 


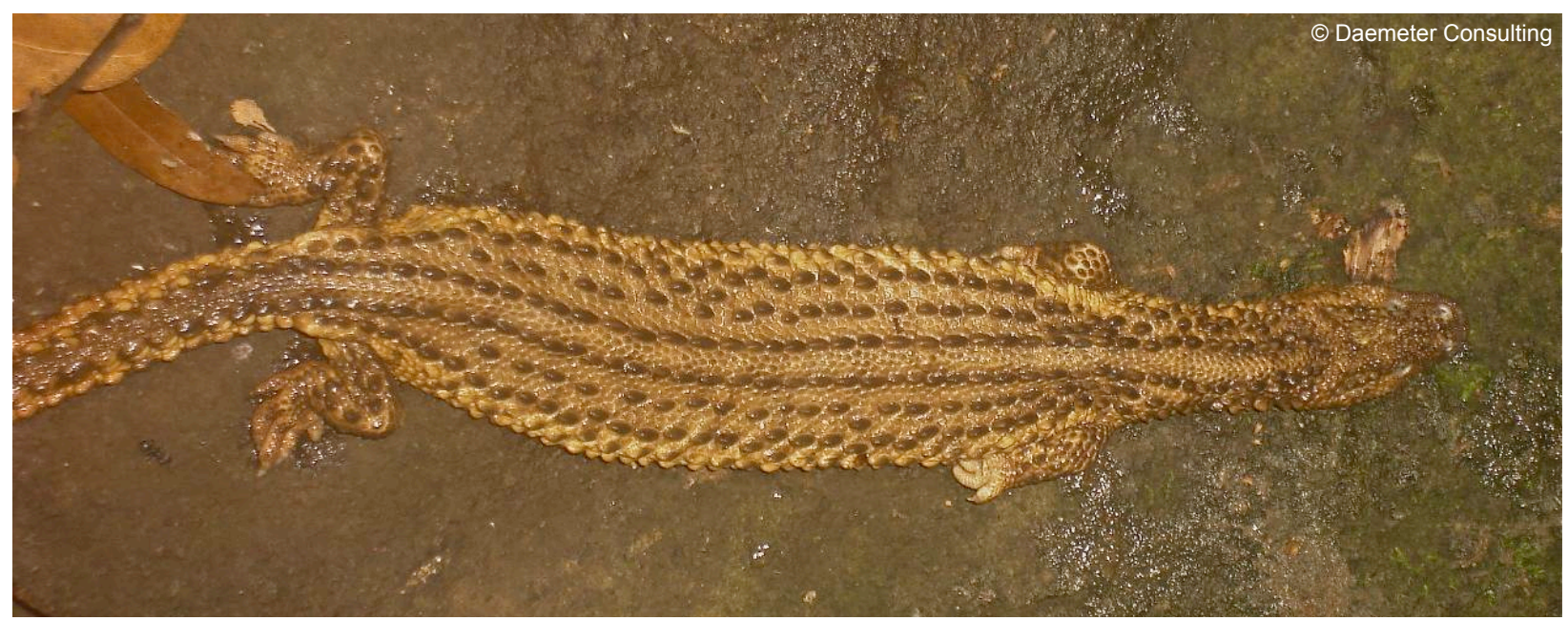

Image 4. Lanthanotus borneensis laid out on a rock. The photo clearly displays the characteristic six longitudinal dorsal rows of enlarged scales that run from neck to tail-base on this species (Pianka \& Vitt 2003).

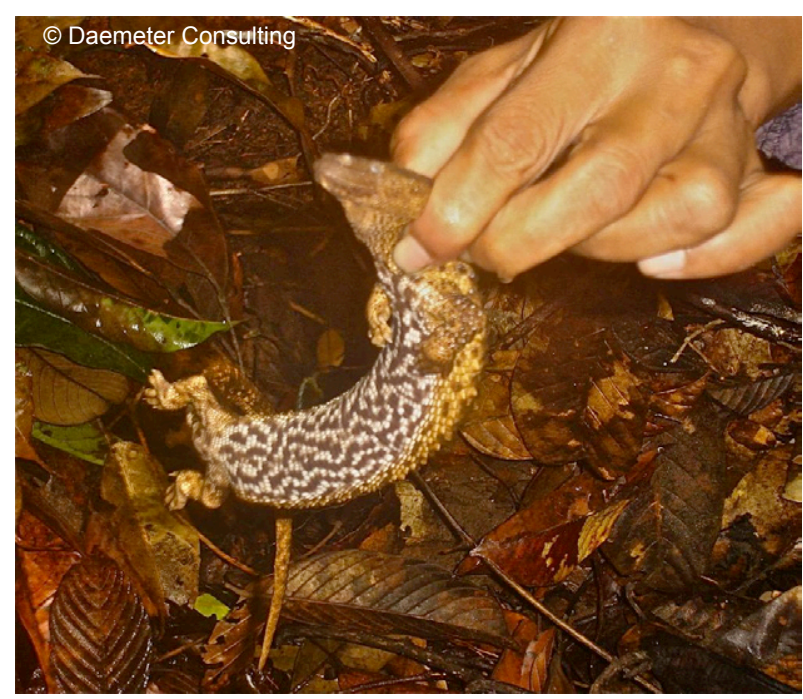

Image 5. Ventral side of Lanthanotus borneensis displaying the characteristic marbling pattern, a mix of white and dark brown, rather than yellow and dark brown as described by the De Rooij (1915).

(belukar) of various ages/stages of regrowth following cultivation. At a broader spatial scale, until recently the surrounding landscape, connecting all the way up to the Sarawak border and beyond, could be described as a human dominated mixed rubber agroforestry/ shifting agriculture mosaic stretching for several hundred kilometers from Bengkayang through to Landak, interrupted by small islands of natural forest on steep hills or infertile elevated plateaus. Large intact blocks of forest have been relatively few and isolated for the past several decades.

\section{Community interviews}

Team members from the local community (eight of which were present when the lizard was found) were not interviewed directly about the lizard, but they registered no clear surprise or interest in the animal. They referred to it as kadal, the generic Indonesian word for lizard, usually including skinks and agamids. Interestingly, the local term for monitor lizards is biawak, but it was not used in reference to $L$. borneensis.

The social team that discovered the lizard was part of a larger High Conservation Value (HCV) assessment team undertaking surveys at six different sites across Landak and Sanggau districts at the time. These surveys included expert teams surveying social aspects, biodiversity (plants, birds and mammals) and environmental services. As part of the biodiversity surveys, community interviews were held with hunters and other community members who frequently spend time in the forest, e.g., tapping rubber trees or hunting. These interviews aimed to identify faunal species that still occur in the areas of the proposed estates and to describe their distribution, habitat and local abundance. A picture book with images of mammals, birds, and a select group of reptiles and plants was used as a visual aid for these interviews, which were conducted in village settlements and/or forest locations.

The location where L. borneensis was discovered was surveyed in two phases - first when the specimen was discovered in May 2008, and second in August 2008. For the second phase of the survey, $L$. 


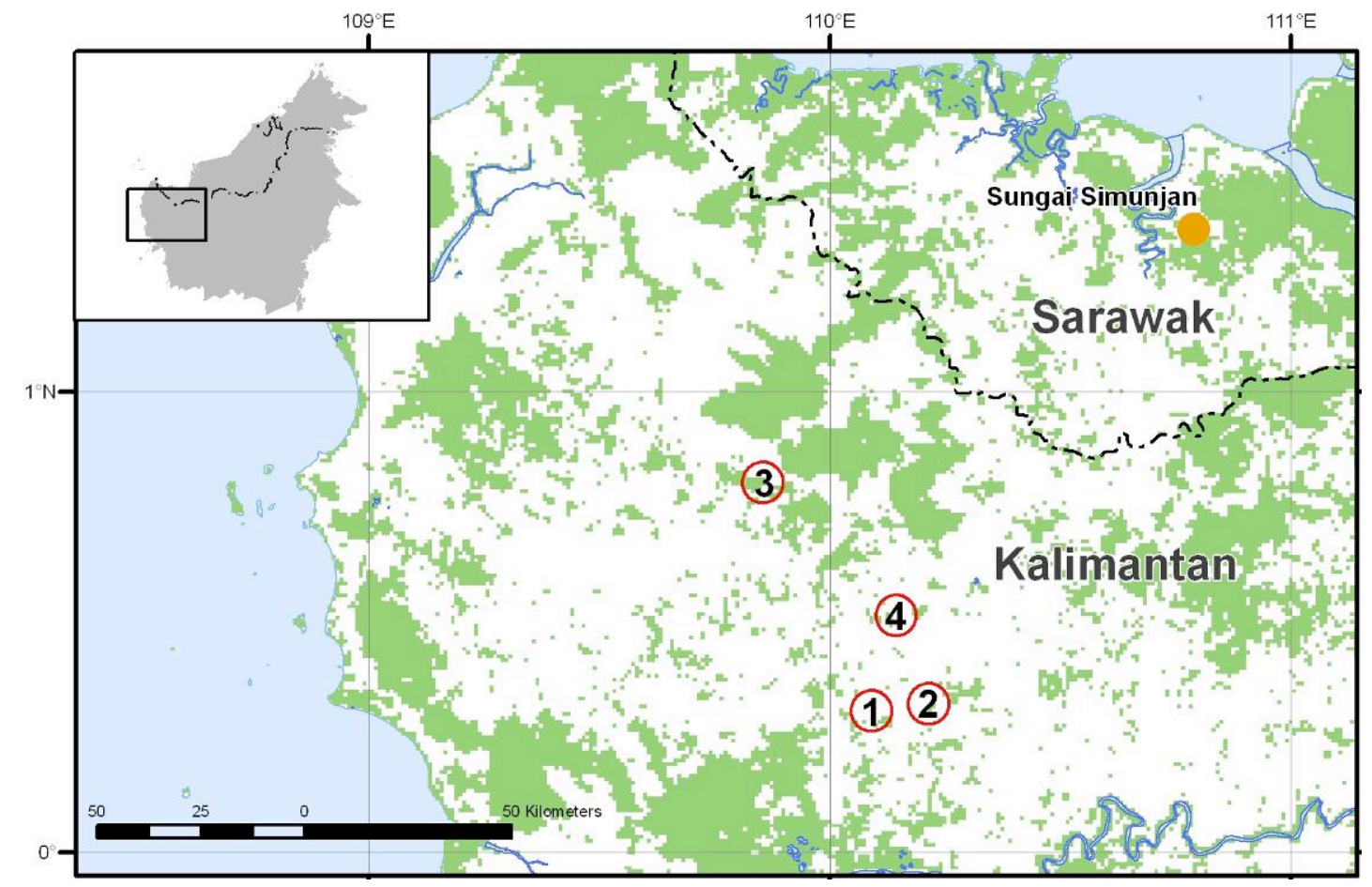

Image 6. Localities surveyed in Landak District of West Kalimantan overlaid with 2007 forest cover.

borneensis was added to the picture book, displayed alongside three other Varanus spp.: Varanus salvator, $V$. rudicollis, both native to Borneo and the Australian $V$. varius. The same picture book was used in surveying three other estates, one neighboring and two that are located progressively closer to the Sarawak border (Image 6).

Interview results suggest the species is more broadly distributed in the Landak Districtand into the neighboring Sanggau District. Although interview data as a basis for biodiversity survey has inherent limitations, including respondent errors or (worse yet) intentional misleading, in the present case, the areas surveyed are largely rural, remote and ethnically Dayak, with a tradition of forest dependency, meaning people spend a large amount of time in the forests near their villages and many hunt on a regular basis. Under these conditions, interview data is expected to be more reliable.

Interview results for $L$. borneensis suggest that the species is widely known by local residents. The species was most frequently described as inhabiting immature forest, tembawang and river edges. Table 1 below presents interview results, including occurrence. In the estate where the reported specimen was observed (Estate 1, Table 1), 62\% of respondents ( 8 of 13) reported the species to be present in their area. The neighboring estate (Estate 2 in Table 1) to the east reported even higher frequencies, with $81 \%$ of respondents (17 of 21) reporting the species to be present. Moving north, towards the border of Sarawak, $100 \%$ of respondents (6 of 6) in Estate 3 and 81\% (17 of 21) in Estate 4 also reported L. borneensis to be present in their area (see Table 1).

\section{Description and taxonomy}

Since its description by Steindachner in 1877 , most studies on the enigmatic Lanthanotus borneensis have focused on systematic relationships among the superfamily Varanoidea and its sister group, the snakes, Serpentes (e.g., Boulenger 1899; McDowell \& Bogert 1954; Underwood 1957; Mertens 1961; Maisano et al. 2002).

Table 1. Community interview results regarding presence of Lanthanotus borneensis

\begin{tabular}{|l|c|c|c|c|}
\hline Estate & $\begin{array}{c}\text { No. } \\
\text { interviews }\end{array}$ & $\begin{array}{c}\% \\
\text { responded } \\
\text { present }\end{array}$ & $\begin{array}{c}\% \\
\text { responded } \\
\text { common }\end{array}$ & $\begin{array}{c}\% \\
\text { responded } \\
\text { rare }\end{array}$ \\
\hline Estate 1 & 13 & 62 & 23 & 31 \\
\hline Estate 2 & 21 & 81 & 43 & 29 \\
\hline Estate 3 & 21 & 81 & 86 & 14 \\
\hline Estate 4 & 6 & 100 & 0 & 80 \\
\hline
\end{tabular}


The species' unique morphology, i.e., no external ear opening, small eyes and nares, bead-like longitudinal dorsal scale rows, small limbs, cylindrical body, increased number of vertebrae, prehensile tail, forked tongue and lower eye-lids with translucent windows (Steindachner 1877; Pianka 2004), had already prompted Steindachner to include this species into the monospecific family, Lanthanotidae.

However, according to Boulenger (1899) osteological features of Lanthanotus borneensis rather confirmed the affinity to the gila monsters Helodermatidae than provided evidence for the proposed Lanthanotidae by Steindachner. While De Rooij (1915) included L. borneensis in the Helodermatidae, a study by McDowell and Bogert (1954) then ruled out phylogenetic relationships to the Helodermatidae and to that of the Chinese Crocodile Lizard Shinisaurus crocodilurus, and re-established the family of the Lanthanotidae.

Findings of Rieppel (1980) revealed the postcranial skeleton morphology is intermediate in structure between Heloderma and Varanus, while studies of the hemipeneal structure in Lanthanotus and Varanus reveal a unique synapomorphy not existent in Heloderma (Branch 1982).

To date, fossil records remain scarce and only one, Cherminotus longifrons, from the Upper Cretaceous of Mongolia, may represent the clade Lanthanotidae (Borsuk-Biaynika 1984; Carroll 1988). According to McDowell and Bogert (1954), L. borneensis finds its ancestors in the semi-aquatic reptiles, the aigialosaurs and dolichosaurs. Later authors further add that $L$. borneensis may perfectly resemble an ancestor of snakes, in having similarities with blind snakes, boids and colubrids, which emphasizes the hypotheses that snakes derived from the infraorder Varanoidea (Helodermatidae, Varanidae, Lanthanotidae). In 1992, Carroll\&DeBragaproposedafirstphylogeneticanalysis placing Lanthanotus/Varanus and Cherminotus/ Saniwa (with Saniwa recognized as a fossil varanoid) clades in a polytomy with aigialosaurs.

However, despite ongoing research to clarify ancestral lineages of today's extant squamates (i.e., that of varanids and snakes), the combination of all morphological traits of $L$. borneensis and its inclusion in a mono-typic family together with a fossil record from the cretaceous may allocate the species as a "living fossil" and proves its high value for evolutionary research.

\section{Sarawak specimen}

To date, all recorded specimens of $L$. borneensis have been collected in Sarawak, Malaysia. In 1848, Low presented the first checklist of Borneo's herpetofauna, including L. borneensis, revealing (1) the rarity and secretive/nocturnal live habits of this lizard, and (2) that herpetological explorations in the former British Borneo (Sarawak, Brunei Darussalam, Sabah) were conducted more frequently than in former Dutch Borneo, today's Kalimantan (Indonesian Borneo) (Das 2004). Since its description in 1877, only 12 specimens had been found up until 1961 (Proud 1978). In 2004, Pianka noted that "only about 100 of these lizards have ever been collected", all recorded and collected from Sarawak (Das \& Yaakob 2007). In addition to the rarity of its collection, much of the information published on L. borneensis are reports on behavioural observations of single specimens kept in captivity (e.g., Harrison \& Haile 1961; Harrison 1961, 1963, 1966; Mertens 1961, 1966). Little is therefore known of its behavior in its natural habitat from these Sarawak specimens.

\section{Conclusion}

In light of this published discovery of Lanthanotus borneensis for Indonesian Borneo, anecdotal locality records of the species in West Kalimantan by Auliya (2006), and previous locality records in Sarawak, it may be concluded that this species of lizard occurs over a much wider range on the island of Borneo. Its apparent rarity in scientific collections appears to be due to its nocturnal and secretive life habits.

The fuller range of this species, however, could be limited to western Borneo. The historical biogeography of Borneo reflects that species-defined distribution areas largely coincide with tectonic terrains (Yap 2002; Auliya 2006). All records of L. borneensis to date have occurred on the "East Malaya Terrane", a tectonic terrain that covers much of western Borneo (Michaux 1995), but does not encompass the remainder of Kalimantan, Brunei Darussalam and Sabah. The absence of records in these areas, especially in wellsurveyed areas of Sabah, and its recent discovery further south in the East Malaya Terrane, supports this possibility. Yet, the overall paucity of knowledge on the population status, distribution pattern (the species is not listed in the IUCN Red List of 2012) and natural history traits of this species makes this difficult to 
confirm. Ongoing habitat conversion across the island of Borneo raises concern over population fragmentation and viability. Future discoveries are likely to go undocumented under current land clearing and environmental monitoring practices.

The record presented here provides useful observational notes on habitat utilized by Lanthanotus, data considered valuable, as the species' life history remains poorly known. Although this specimen was found in a forest fragment located in an oil palm plantation, deforestation and conversion to agricultural land uses are known to have a severe impact on species richness of forest herpetofauna (cf. Sodhi et al. 2010). Based on current, limited knowledge of the life history of this species, reduced canopy cover, the drainage of small water bodies and changes in riverine microhabitats are likely to have an impact on its longterm survival (also cf. Wanger et al. 2010). A long-term study on the distribution pattern and natural history of Lanthanotus is strongly recommended in order to better understand and preserve this evolutionary unique vertebrate and its habitat on the island of Borneo.

Finally, the record highlights the important role industry can play in identification (and potentially management) of poorly known species such as $L$. borneensis. Though private-sector engagements in social and environmental surveys, as illustrated here, are unusual for the oil palm industry, they hold obvious value and should be encouraged.

\section{REFERENCES}

Auliya, M. (2006). Taxonomy, Life History, and Conservation of Giant Reptiles in West Kalimantan. Natur und Tier Verlag, Münster, 432pp.

Auliya, M. (In prep.) Annotated Checklist of Amphibians and Reptiles in Kalimantan (Indonesian Borneo).

Belcher, S.E. (1848). Narrative of The Voyage of H.M.S. Samarang During the Years 1843-46: Employed Surveying The Islands of The Eastern Archipelago. With Notes on the Natural History of The Islands. Reeve, Benham and Reeve, London.

Bodmer, R.E., R.J. Mather \& D.J. Chivers (1991). Rain forests of Central Borneo - threatened by modern development. Oryx 25: 21-26.

Borsuk-Bialynika, M. (1984). Anguimorphans and related lizards from the late Cretaceous of the Gobi Desert, Mongolia. Palaeontologia Polonica 46: 5-105.

Boulenger, G.A. (1899). (On Lanthanotus borneensis). Proceedings of the Zoological Society of London 39: 596-
597.

Branch, W.R. (1982). Hemipeneal morphology of platynotan lizards. Journal of Herpetology 16: 16-38.

Carroll, R.L. (1988). Vertebrate Paleontology and Evolution. W.H. Freeman and Company.

Carroll, R.L. \& M. DeBraga (1992). Aigialosaurs: midCretaceous varanoid lizards. Journal of Vertebrate Paleontology 12: 66-86.

Curran, L.M., S.N. Trigg, A.K.Mc Donald, D. Astiani, Y. M. Hardiono, P. Siregar, I. Caniago \& E. Kasischke (2004). Lowland forest loss in protected areas of Indonesian Borneo. Science 303: 1000-1003.

Das, I. (2004). Collecting in the "Land Below the Wind", Herpetological Explorations of Borneo. Bonner Zool. Beiträge 52(3/4): 231-243.

Das, I \& N. Yaakob (2007). Status of knowledge of the Malaysian herpetofauna. In: Status of biological diversity in Malaysia and threat assessment of plant species in Malaysia, pp. 31-81. In: Chua L.S.L., L.G. Kirton \& L.G. Saw (eds.). Status of Biological Diversity in Malaysia and Threat Assessment of Plant Species in Malaysia. Forest Research Institute Malaysia, Kepong.

De Rooij, N. de (1915). The Reptiles of the Indo-Australian Archipelago. I. Lacertilia, Chelonia, Emydosauria. Leiden (E.J. Brill), xiv+384pp.

Fuller, D.O., T.C. Jessup \& A. Salim (2003). Loss of Forest Cover in Kalimantan, Indonesia, Since the 1997-1998 El Niño. Conservation Biology 18: 249-254.

Harrison, B. (1961). Lanthanotus borneensis - Habits and Observations. Sarawak Museum Journal 10(17-18): 286292.

Harrison, T. (1963). Lanthanotus borneensis - the first 30 Live Ones. Sarawak Museum Journal 11(21-22): 299-301.

Harrison, T. (1966). A record-size Lanthanotus alive (1966): Casual Notes. Sarawak Museum Journal 14: 323-334.

Harrison, T \& N.S. Haile (1961). A rare Earless Monitor Lizard from Borneo. Nature 190(4782): 1213.

Low, H. (1848). Sarawak: Its inhabitants and productions being notes during a residence in that country with His Excellency Mr. Brooke. Richard Bentley. London, 416pp. [Reprinted 1990 by Pustaka Delta Pelajaran Sdn Bhd., Petaling Jaya, Malaysia].

MacKinnon, J. (1997). Protected Areas System Review of the Indo-Malayan Realm. Asian Bureau for Conservation, in collaboration with the World Conservation Monitoring Centre. Cambridge, UK.

MacKinnon K., G. Hatta, H. Halim \& A. Mangalik (1996). The Ecology of Kalimantan. The Ecology of Indonesia Series, Volume III. Periplus Editions (HK) Ltd.

Maisano, J.A., C.J. Bell, J.A. Gauthier \& T. Rowe (2002). The Osteoderms and Palpebral in Lanthanotus borneensis (Squamata: Anguimorpha). Journal of Herpetology 36(4): 678-682.

Malkmus, R., U. Manthey, G. Vogel, P. Hoffmann \& J. Kosuch (2002). Amphibians and Reptiles of Mount Kinabalu (North Borneo). A.R.G. Gantner Verlag K. G., 
Rugell. 424pp.

McDowell, Jr., S.B. \& C.M. Bogert (1954). The systematic position of Lanthanotus and the affinities of the anguinomorphan lizards. Bulletin of the American Museum of Natural Histotry 105(1): 1-142.

Mertens, R. (1961). Lanthanotus: an important lizard in evolution. Sarawak Museum Journal 10 (17-18 (new ser.)): 283-285.

Mertens, R. (1966). The Keeping of Borneo Earless Monitors (Lanthanotus borneensis). Sarawak Museum Journal 14: 320-322.

Michaux, B. (1995). Distributional patterns in West Wallacea and their relationship to regional tectonic structures. Sarawak Museum Journal XLVIII, 69: 163-179.

Mocquard, F. (1890). Recherches sur la faune herpetologique des Iles de Borneo et de Palawan. Nouvelles archives du Museum d'histoire naturelle de Paris, Ser. (3)2: 115-168.

Pianka, E.R. (2004). Lanthanotus borneensis, pp. 535-538. In: Pianka E.R. \& D.R. King (eds). Varanoid Lizards of The World. Indiana University Press, Bloomington, IN, USA. $588 \mathrm{pp}$.

Pianka, E.R. \& L.J. Vitt (2003). Lizards: Windows to The Evolution of Diversity - Lanthanotidae. University of California Press, Berkeley.

Proud, K.R.S. (1978). Some notes on a captive earless monitor lizard, Lanthanotus borneensis. Sarawak Museum Journal 26 (47): 235-242.

Rieppel, O. (1980). The postcranial skeleton of Lanthanotus borneensis (Reptilia, Lacertilia). Amphibia-Reptilia 1: 95-112.

Sodhi, N.S., L.P. Koh, R. Clements, T. C. Wanger, J.K. Hill, K.C. Hamer, Y. Clough, T. Tscharntke, M.R.C. Posa \& T.M. Lee (2010). Conserving Southeast Asian forest biodiversity in human-modified landscapes. Biological Conservation 143: 2375-2384.

Steindachner, F. (1877). On two new genera and species of lizards from South America and Borneo. Annals and Magazine of Natural History (4)20: 160.

Underwood, G. (1957). Lanthanotus and the anguinomorphan lizards: a critical review. Copeia 1957(1): 20-30.

Wanger, T.C., D.T. Iskandar, I. Motzke, B. W. Brook, N.S. Sodhi, Y. Clough \& T. Tscharntke (2010). Effects of Land-Use Change on Community Composition of Tropical Amphibians and Reptiles in Sulawesi, Indonesia. Conservation Biology 24(3): 795-802.

WWF Germany (2005). Borneo: Treasure Island at Risk. Status of Forest, Wildlife and related Threats on the Island of Borneo. WWF Germany, Frankfurt a. Main, 78pp.

Yaap, B., M. Struebig, G.D. Paoli \& L.P. Koh (In press). Mitigating the biodiversity impacts of oil palm development. CAB Reviews: Perspectives in Agriculture, Veterinary Science, Nutrition and Natural Resources.

Yap, S.Y. (2002). On the distributional patterns of SoutheastEast Asian freshwater fish and their history. Journal of Biogeography 29: 1187-1199. 